\title{
Marketing and Promotion of E-journal in Academic Libraries in Tanzania
}

\author{
Joseph Cassian Pessa \\ Institute of Social Work Library, Institute of Social Work, Dares Salaam, Tanzania
}

Email address:

j.pessa@isw.ac.tz, oespessa@yahoo.com

\section{To cite this article:}

Joseph Cassian Pessa. Marketing and Promotion of E-journal in Academic Libraries in Tanzania. American Journal of Information Science and Technology. Vol. 3, No. 1, 2019, pp. 10-16. doi: 10.11648/j.ajist.20190301.12

Received: January 15, 2019; Accepted: February 21, 2019; Published: March 15, 2019

\begin{abstract}
This paper examines promotion and marketing strategies used by academic libraries in Tanzania to make users aware of the availability of e-resources. To collect data, this study used survey. Data were analyzed using an Independent TTest and One-Way MANOVA using SPSS Version 16. Documentary review of secondary data related to the study was done. Major findings of the study revealed that e-journals are being used in Universities and Colleges in Tanzania despite the various challenges. Various marketing strategies such as use of OPAC, the Web 2.0 and others were used for informing users about a range of available e-resources in academic libraries and thus promoting their access and use. Finally, the recommendations for enhancing the marketing of e-resources are given.
\end{abstract}

Keywords: Electronic Resources, E-journal, Marketing, Library and Tanzania

\section{Introduction}

Many academic libraries and Universities have invested millions of dollars on Information and Communication Technologies [1]. Increasingly, these technologies are used to improve subscription and access to electronic journals. Basically, libraries use a substantial amount of their annual budgets on subscriptions to electronic resources which provide many advantages over conventional print journals [23]. Findings from a study done in USA, Canada, Brazil, Argentina, Chile, Mexico, Columbia, Peru, Venezuela, Uruguay, Europe, Asia, Saudi Arabia, Turkey and Israel show that $71 \%$ of their academic institutions subscribe to ejournals. Similar findings were also evident in Africa in countries such as: Angola, Ghana, Kenya, Nigeria, and South Africa where spending on e-resources increased annually [4].

To ensure the massive information now generated in electronic format is availed to users, several initiatives have been taken. In some universities the requisite network infrastructure, hardware and software have been provided. Under very specific circumstances in certain countries in Africa access to journals and databases is now free or at profoundly low-price through programmes like Access Global Online Research in Agriculture (AGORA), Access to Research Initiatives HINARI, The Essential Electronic
Agriculture Library (TEEAL), Programme for Enhancement of Research Initiative (PERI), International Network for the Availability of Scientific Publications (INASP), Electronic Information for Libraries (elFL) and Online Access to Research on Environment (OARE). This is as a result of negotiation with publishers [5]. Although ICT has improved information sharing and access to e-resources and services in academic libraries, many of them are unknown to the users and hence underutilized [6-8]. Users' level of awareness of available services and e-resources in academic libraries is low. Awareness of the available e-resources is crucial to influence usage [5]. Academic libraries have not adequately developed marketing strategies to promote awareness, access to and use of e-resources to clients and compel them to select library's services and e-resources [9]. Seemingly, marketing is still not adequately used as a strategy for informing users about a range of services that a library can provide. Nowadays, many companies market their products and services online to increase visibility and users' consciousness. Several tools which have remarkable marketing advantages in terms of audience, time and cost reduction are used. Therefore, academic libraries cannot continue to sit in their comfort zones waiting for customers, that is, students, faculty, and staff to use their services. 


\subsection{Statement of the Problem}

Academic libraries in Tanzania have excellent electronic products and services. Nonetheless, due to lack of overt strategic marketing approaches, many users are unaware of their availability. This is mainly because of the fact that marketing is not given due priority as a tool for promoting access to and use of e-resources [10]. There is a misconception that marketing is all about selling not knowing that it is a total library effort to attract, satisfy, and sustain the interest of users. Also, because of the myopic view that library services and products are so vital that users will still use them as they have always done without additional effort from the librarians [11]. Many libraries over look the allocation of funds for marketing to the extent that promotional activities are created at a minimal cost by the librarians [12]. There are only few empirical studies on the marketing of e-library resources in academic libraries in Tanzania. Given this, this study is developed to examine the use of electronic journals and identify the promotion and marketing strategies used by academic libraries in Tanzania.

\subsection{Objectives of the Study}

1. To examine the use of electronic journals in academic libraries in Tanzania

2. To identify factors limiting the access and use of ejournals in academic libraries in Tanzania

3. To assesss the promotion and marketing strategies used by academic libraries inTanzania

\section{Theoretical Review}

\subsection{Use of E-journals}

In America, Europe and Asia electronic journals are increasingly becoming important to academic staff, researchers and students than the use of print journals [13]. Similarly, realizing their importance in Africa, several studies done in Nigeria, Malawi, Rwanda, Kenya, Tanzania show that in some Universities e-journals, electronic books and other e-resources are being subscribed [6, 14-16]. This is facilitated by increased investment in requisite technological infrastructure. Many Universities in these countries have wireless links, Local Area Network (LAN), Internet, Intranet and backup generators to ensure business continuity even during a power blackout. As aresult, they have a range of high-quality peer-reviewed e-journals and leading journals from major international publishers. Although academicians, students and researchers can have access to full-text electronic journals from their offices, the library computer lab section, from their laptops and even smartphones just free of charge or at a profoundly low-price [5, 17], their negative attitude and behaviour still do not promote technological access and use. Libraries have not adequately influenced the behaviour and approach of their users through advocacy and training [5]. Even though connectivity is gradually improving, reliable high-speed broadband connections are still not guaranteed in many countries.

\subsection{Marketing of E-resources}

Although academic libraries spend a lot of money on eresources, many of them are unknown to the users and hence underutilized. Despite the fact that marketing is crucial, now than before, Libraries have not adequately marketed these resources to their users. Inacademic libraries marketing is accorded low priority [18]. This is despite the fact that proper marketing of e-journals can help libraries to segment their customers into specific user groups, better understand their users' needs, identify their "marketniche" and advertise directly to them after establishing the type of products and services to be marketed to them based on their specific needs. By marketing librarians can establish users' statistics and create "quick re-direct Weblog" which can enable them determine use of e-resources and track the number of times a particular link is accessed. Thus, the library management will identify the e-resources underutilized and make informed decisions about the resources which should stay, be dropped or marketed $[19,20]$.

\subsection{E-marketing Strategies for Libraries}

Library marketing is essential should the libraries operate at a competitive advantage. It helps the library, differentiate its services from those of its competitors and build its brand and image. Various marketing strategies can be used for informing users about a range of available services and eresources in academic libraries and thus promoting access to and use of these resources [21, 22]. To increase users' awareness of e-resources available to them, academic libraries across the world, market their products and services online using various strategies such as the Internet and webpages to encourage the use of e-resources [21]. Also, academic libraries are increasingly using Web2.0 tools, faculty outreach to promote users' access and use of ejournals and other resources [23]. This includes the use of mobilephones to access e-journals conveniently. These enable patrons to use mobile optimized websites to search for and access e-journals via their respective library websites on their phones. Apart from the modern marketing tools that promote their e-services, libraries are still using the traditional methods of print materials as well as displays [23] and [24].

\subsection{Theoretical Framework}

Over the years, research on information technology acceptance has developed numerous competing models. These include the Theory of Reasoned Action (TRA), Theory of Planned Behaviour (TPB), Technology Acceptance Model (TAM), Technology Acceptance Model (TAM2), Diffussion of Innovation Model (DOI) and Unified Theory of Acceptance and Use of Technology (UTAUT). Several studies used UTAUT Model to find drivers and modifiers of user acceptance of e-journals in higher education [25]. Their results validated UTAUT construct with Performance 
Expectancy (PE) as the most important driver for marketing of e-journals. Another study by Carlsson [26] also used UTAUT to explain acceptance of mobile devises or services in Finland, and found that PE and effort expectancy (EE) were significant but Social Influence (SI) was not. This study also empirically utilized the validated UTAUT model to explain technology adoption and determine factors influencing usage of e-journals in academic libraries. The proposed UTAUT model was examined with six independent scales: Trust (TR), Performance Expectancy (PE), Efforts Expectancy (EE), Social Influence (SI), Website Quality (WQ), and Facilitating Condition (FC). These seven key constructs are the determinants of usage intention and behavior. Drawing from the UTAUT Model this study also explains how individual differences in terms of gender and designation influence technology (e-journal) use. To draw its conclusion the study also considered PE, EE, SI, WQ and FC as factors influencing users to access and use e-journals.

\section{Materials and Methods}

This study is based on data collected in two academic libraries using surveys. The study was conducted at UDSM and OUT. Data were analyzed using an Independent T-Test and One-Way MANOVA using SPSS Version 16. Morespecifically, anindependent t-test was performed to explore gender differences in users' preference to access and use e-journals between males and females. Multivariate Statistical Analysis (MANOVA) was also conducted to explore the variation in the preference of users to access and use e-journals between students and lecturers. Using SPSS, the percentages of respondents in favor of using electronic journals per day or week were computed. The choice of academic libraries was justified by their relatively increased use of e-journals.

\section{Results and Discussion}

\subsection{Demographic Characteristics of Respondents}

A randomly selected sample of 140 respondents was requested to complete a survey, with a response rate being $80 \%$ (112 respondents). Out of these $67(60 \%)$ respondents came from UDSM and $45(40 \%)$ came from OUT. The majority $100(89 \%)$ of them were aged between 25 and 55years (SeeTable1). A closer analysis shows that most of the respondents were young and easily adapted to the technology.

Table 1. Demographic characteristic of respondents.

\begin{tabular}{lllll}
\hline S/No & Age & UDSMN=67 & OUTN=45 & TOTALN=112 \\
\hline 1 & $25-35$ & $41(36 \%)$ & $5(5 \%)$ & $46(41 \%)$ \\
2 & $36-45$ & $13(12 \%)$ & $9(8 \%)$ & $22(20 \%)$ \\
3 & $46-55$ & $13(12 \%)$ & $19(17 \%)$ & $32(28 \%)$ \\
4 & 56 Yearsandabove & $0(0 \%)$ & $12(11 \%)$ & $12(11 \%)$ \\
5 & TOTAL & $67(60 \%)$ & $45(39 \%)$ & $112(100 \%)$ \\
\hline S/No & & & TOTALN=112 \\
1 & Age & UDSMN=67 & OUTN=45 & $44(40 \%)$ \\
2 & Male & $24(22 \%)$ & $20(18 \%)$ & $68(60 \%)$ \\
3 & Female & $43(38 \%)$ & $25(22 \%)$ & $112(100 \%)$ \\
\hline
\end{tabular}

\subsection{Use of Electronic Journals in Tanzania}

Over half of the library patrons use electronic journals on a regular basis. Out of these, $60 \%$ access e-journals on weekly and $25 \%$ on daily basis. As regard users' preference to access and use e-journals, the paired-samples t-test revealed a statistically significant gender difference between males $(\mathrm{M}=4.14, \mathrm{SD}=1.12)$ and female $(\mathrm{M}=2.39, \mathrm{SD}=1.46): \mathrm{t}(58)=$ $6.224, \mathrm{p}<.0005$. The eta square statistic (.40) indicated a large effect size. Notably, there is a male predisposition in using computer and Internet and time spent online. Fewer women than men are Internet users. While gender differences abound, a one way between groups MANOVA revealed no statistically significant difference in the accessibility of ejournals between students and teachers $F(2,56)=2.053$, $\mathrm{p}=.138$; Wilks'Lambda=.932. Drawing from the findings above, it is evident that e-journals are now being used in UDSM and OUT where, traditionally, the number of males is higher than that of female users. This is contrary to the findings by Ndungu [12] and Hikmany [10]. E-journals that are commonly used include Blackwell as pointed out by $77(69 \%)$ respondents, JSTOR $73(65 \%)$ respondents, Springer, $73(65 \%)$ respondents, Emerald 71 (63\%) respondents, AJOL 72(64\%) respondents, AGORA 72(64\%) respondents, Sage 65(58\%) respondents, Wiley Science 65(58\%) respondents, EbscoHost 65(58\%) respondents and HINARI $32(29 \%)$ respondents. Implicitly, the results revealed that the use of Blackwell, JSTOR, Springer and Emerald was rated high, possibly, due to their broadened discipline coverage and visibility. Respondents further said that these e-journals were mostly used for finding research material 100(90\%), material for teaching 67(60\%) and for consultancy $5(5 \%)$. These findings are also reflected in a study by [5, 27, 33], that e-journals are subscribed by Universities and Colleges. The level of access, adoption and use of e-journals for teaching, research and consultancy in UDSM and OUT libraries in Tanzania varies. This variation leads to an information gap between these institutions, individual scholars and researchers. Basically, there are significant differences in terms of the way academic staff use 
e-journals in their daily academic duties. This is due to dissimilarity in the users' working and reading habits among disciplines, their technological capability and gender.

\subsection{Factors Limiting the Access and Use of E-journals in Academic Libraries in Tanzania}

Despite the use of e-journals, still there are several factors limiting users to access and use e-journals. Respondents were asked to indicate the reasons for users' failure to access and use e-journals. As would be expected, unawareness of availability of journals $(\mathrm{M}=3.91)$ ranked high. This was followed by availability of few computers in the library $(\mathrm{M}=3.85)$. Other reasons pointed out were poor connectivity with low speeds $(\mathrm{M}=3.81)$, dropping connections $(\mathrm{M}=3.81)$, Intermittent power supply $(\mathrm{M}=3.81)$ and bandwidth problems $(\mathrm{M}=3.81)$ (See Table 2).

Table2. Factors limiting the access and use of e-journals in academi clibraries.

\begin{tabular}{ll}
\hline Causesofreluctancetousee-journals & MeanScore \\
\hline Un-awareness of availability of journals & 3.91 \\
Few computers & 3.85 \\
Lack of search skills & 3.81 \\
Dropping connections & 3.81 \\
Intermittent power supply & 3.81 \\
Bandwidth problems & 3.81 \\
Poor search skills & 3.75 \\
Un-userfriendly interfaces & 3.75 \\
\hline
\end{tabular}

The results of this paper show that though patrons may be interested to use e-journals, they are currently incapacitated to do so by various technological deprivations as pointed out above. The above findings correlate with those of scholars who maintained that technical barriers ranging from lack of computers to lack of search skills and un-user friendly interfaces that make downloading material difficult cause patrons' reluctance to use e-journals adequately [6] [28] [29] [30] and [17]. Other causes of reluctance and limited access to and use of e-journal, among patrons are poor quality of image and lack of research culture. The poor quality of the image makes users reluctant to read from the screen. Users' reluctance to use e-journals in Higher Learning Institutions is also caused by lack of information searching skills and unawareness of a wide range of e-resources available in the library [31].

\subsection{Methods of Marketing and Promoting the Use of E-journal}

Respondents were provided with twelve marketing tools used by academic libraries as strategies to market e-journals. They were asked to rate the importance of each tool on a five-point scale ranging from Always (1) to Never (5). In both UDSM and OUT, respondents rated Online Public Access (medianscore $=5$ ), as the always used marketing strategy. The web (medianscore=3.5) and social media (medianscore $=3.5$ ) were rated by respondents as most frequently used. These were followed by Fliers and posters (medianscore=3) which were rated as frequently used each. Respondents rated two other strategies as occasionally used (median score=2): namely, Academic staff outreach (medianscore=2) and Training sessions (medianscore=2). Easy to find e-journal links (median score $=1.5$ ) and Mobile access of e-journals (medianscore $=1.5$ ) were rated as rarely used strategies for e-journals marketing. E-mails to academic staff (medianscore $=1$ ) were rated as never used.

Basically, this study found out that libraries have marketing strategies for e-resources. The strategies have proved successful in some Universities such as UDSM and OUT where OPAC, social media, fliers, posters and the web were commonly used. The findings above relate with the study by Muneja [32] which shows that academic libraries in Universities are using OPAC and website to link directly the library and its users. In this way they market their electronic products and services online and increase their visibility in a 247365 formula $[33,34]$. The only weakness with these methods is that many students do not visit the library homepage [20]. Academic libraries are also increasingly using Web2.0 tools such as social media, Twitter, blogs, wikis, You Tube and Facebook to market their services [35] [33] [36-43] and [44]. By using You Tube, libraries attach videos to market their e-services. Libraries also give the traditional and cross-functional promotional print materials/ tools such as library publications, fliers, brochures and posters regularly to library customers [33] [45, 46] as marketing tools that promote their e-services and e-resources.

Alternatively, smartphones, laptops and tablets are significantly used to facilitate mobile access and use of ejournals conveniently [47]. This implies that mobile devices are being used to support the Online Library System whereby by using the mobile optimized website users are now searching for and access e-journals via their respective library websites. To ensure users access the contents of smartphones, Libraries in their library policies are now allowing users to use their mobile phones. These were prohibited in the past. Now libraries are licensed third-party apps. These apps allow users to create digital book shelves of e-journals from multiple publishers. These findings are also supported by a study by [33] that the increasing prevalence of mobile devices such as apps for iOS and Android creates a new opportunity for access of e-journal content in smartphones. Drawing from the above, it is evident that library marketing is a crucial management tool for promoting customers' access to e-journals. It increases library credibility, users' awareness and exposure to the available ejournals and hence meeting users' expectations.

Respondents, further, pointed out that other strategies used to influence the marketing and use of e-journals in their libraries include the library marketing committee $(\mathrm{M}=1.9)$, librarypolicy $(\mathrm{M}=1.4)$, and strategic plan $(\mathrm{M}=1.3)$. Additional strategies used are training of users $(\mathrm{M}=1.2)$, setting a financial plan $(\mathrm{M}=1.2)$ and management support $(\mathrm{M}=1.2)$ (SeeTable3). These findings are in line with the findings by Smith (2011) who revealed that library marketing committee is the tool for identifying e-resources and services 
to be promoted thus validating their continued funding, increased awareness and use among the library patrons. On the otherhand, the strategic plan and the policies provide goals and guidelines for establishment of e-library services and training of users.

Table 3. Library Committee, Policy and Marketing Committee.

\begin{tabular}{lll}
\hline & Mean & Std Deviation \\
\hline Marketing Committee & 1.9600 & .20000 \\
Budget & 1.2400 & .43589 \\
Strategic Plan & 1.3200 & .47610 \\
Management Support & 1.2000 & .40825 \\
Library Policy & 1.4000 & .50000 \\
Training & 1.2800 & .45826 \\
\hline
\end{tabular}

\section{Conclusions}

Several conclusions are drawn from this study. Academic libraries in Universities in Tanzania are increasingly subscribing to electronic information resources. The study has shown that there are still not able significant factors limiting access to electronic journals coupled with lack of information searching skills and unawareness of a widerange of e-resources available in the library. Various marketing strategies are now used for promoting eresources access and use. However, the level of adoption and use of these resources vary between Universities and libraries.

\section{Recommendations}

Based on the findings, the following recommendations are made to enhance user's optimum access to and use of eresources:

(1) Universities and colleges should use proactive marketing strategies such as newsletters, posters, flyers and brochures as well as workshops/ training, exhibitions, graduation ceremonies, conferences and academic fairs to publicize e-resources to influence their usage.

(2) Libraries should integrate e-resources, databases into their Websites/ in their OPAC to allow greater visibility and enable users to access full-text from the online catalogue.

(3) Users should be acquainted with the requisite search skills on the use of e-resources' databases and initiate a strategy of "moving out of the library and going to the people" to conduct training where many users would be reached.

(4) The libraries' webpages should provide an online guide and various search-options to scholarly e-resources.

(5) Libraries should address contextual and technical issues such as awareness on available e-resources and access restrictions such as passwords inorder to promote usage levels.

(6) Libraries should identifye-resources which are under utilized to find out ways to market them.

\section{References}

[1] Basri, W., Alandejani, J. A. and Almadani, F. M. (2018). ICT Adoption Impacton Students' Academic Performance: Evidence from Saudi Universities, Education Research International Volume 2018, https://doi.org/10.1155/2018/1240197.

[2] Tyner, K. (2014), Literacy in a digital world: teaching and learning in the age of information. NewYork:Routledge.

[3] Okite-Omughoro, F. A., Makgahlela, L. and Bopape, S. (2014), Theuse of Electronic Information Resources for Academic Research by Postgraduate Students at Delta State University, Abraka, Nigeria, Sajlis Journal 80(2).

[4] PCG (2017). Library Budget Predictions 2017. Results from a Telephon eSurvey. Available online at http:/www.pcgplus.com/wp-content/uploads/ 2017/05/ Library-Budget-Predictions-for-2017-public.pdf Accessed on 07.01.2019.

[5] Msagati, N. (2014), Awareness and Use of Scholarly Electronic Journals by Members of Academic Staff: A Case Study of the DaresSalaam University College of Education (DUCE). Library Philosophy and Practice (e-journal).1124. $\mathrm{http} / / /$ digitalcommons.unl.edu/libphilprac/1124.

[6] Malemia, L. (2014), "The Use of Electronic Journal Articles by Academics at Mzuzu University, Malawi”. Library Philosophy and Practice (e-journal). Paper 1097. Available online at http://digitalcommons.unl.edu/libphilprac/1097.(Accessed on 23.10.2017).

[7] Baro, E. E. (2011), "Awareness and use of online information resources by medical students at Delta State University in Nigeria", Library HiTech News, Vol. 28 Iss:10, pp. 11-17.

[8] Harle, J. (2010), Growing Knowledge: Access to Research in Eastern and Southern African Universities. ACU many Spotlight, No. 1. Available Online at http://www.acu.ac.uk/Arcadia_Growing_Knowledge.pdf (Accessed 23.10.2016).

[9] Chartered Institute of Marketing (2009), Marketing and the 7Ps: a brief summary of marketing and how it works. Maidenhead, UK: CharteredInstitute of Marketing. Availableonlineathttp://www.cim.co.uk/files/7ps.pdf.(Acce ssed 5.11.2016).

[10] Hikmany, Seif R. (2014) Accessibility and Use of Electronic Resources in Library Services in Tanzania: The Case of the Bank of Tanzania Library. Masters Thesis, The Open University of Tanzania.

[11] Chegwe, Azuka O. and Anaehobi, Sebastian E. (2015), "Academic Librarians Perception and Attitude towards Marketing of Library Services in Delta State, Nigeria". Library Philosophy and Practice (e-journal). 1282.

[12] Ndungu, M. W. (2016), Promotion of Electronic Resources in Academic Libraries on a Minimal Budget. International Information \& Library Review Vol. 48, Iss. 2, 2016.

[13] Nicholas, D., Huntington, P. and Rowlands, I. (2007), "Ebooks: how are users responding?", (1) Update, Vol. 6 No. 11 , pp. 29-33. 
[14] Katabalwa, A. S. (2016), "Use of Electronic Journal Resources by Postgraduate Students at the University of DarEsSalaam", Library Review, Vol. 65 Issue: 6/7, pp.445460, doi:10.1108/LR-11-2015-0108. Available online at $<$ http://www.emeraldinsight.com/doi/pdfplus/10.1108/LR11-2015-0108>(Accessed on31.05.2017).

[15] OUT (2016), Electronic Books. Available online at $<$ http://www.out.ac.tz:8088/electronicbooks $>$ Accessed on11.02.2017.

[16] Gathoni, N.(2011), Monitoring and evaluation of electronic resources in academic and research institutions in Kenya: a summary report. INASP, Available online at:http://www.inasp.info/file/145da69d42e89201b2a1280c64 ca0571/me-of-e-resourcesinkenya.htm (Accessed 22.10.2016).

[17] Harle, J. (2010), Growing Knowledge: Access to Research in Eastern and Southern African Universities. ACU many Spotlight, No. 1. Available Online at http://www.acu.ac.uk/Arcadia_Growing_Knowledge.pdf(Acc essed 23.10.2016).

[18] Alire, C. A. (2007), "Word-of-mouth marketing: abandoning the academic library ivory tower", New.

[19] Library World, Vol. 108 Nos 11/12, pp. 545-551.

[20] Castaldo, J. C. (2008), Marketing Electronic Resources from the Academic Library Homepage. A Master's Paper for M. S. in L. S. Degree. Available Online at http://ils.unc.edu/MSpapers/3356.pdf.(Accessed11.05.2017).

[21] Murugusen, S. (2007), Understanding Web 2.0. IT Professional 9(4): 34-41.

[22] Kamar, N. (2008), Marketing of Electronic Information Resources: A Case of The J. D. Rockefeller Research Library, Egerton University. Journal of Library and Information Science 34(1)89-93, April.

[23] Yi, Z. (2016), Effective techniques for the promotion of library services and resources. Information Research, 21(1), paper 702.

[24] Mathews, B. (2009), Marketing today's academic library: a bold new approach to communicating with students. Chicago, IL:American LibraryAssociation.

[25] Anderson et al.(2006)

[26] Carlsson, C., Carlsson, J. Hyvönen, K., Puhakainen, J. and Walden, P. (2006). Adoption of Mobile Devices/ ServicesSearching for Answers with the UTAUT. Proceedings of the $39^{\text {th }}$ Hawaii International Conferenceon SystemScience.

[27] DUCE (2013), DUCELIBRARY: Step by step on how to accesse-resources. Available online at $<$ https://ducelibrary.wordpress.com/2013/04/16/step-by-stepon-how-to-access-e-resources/ $>$ (Accessed24.08.2017).

[28] Hepworth, M. \& Duvigneau, S. (2012) Building Research Capacity: Enabling Critical Thinking through Information Literacyin Higher Educationin Africa. Brighton: Institute of Development Studies.

[29] Gathoni, N. (2011), Monitoring and evaluation of electronic resources in academic and research institutions in Kenya: a summary report. INASP, Available online at:http://www.inasp.info/file/145da69d42e89201b2a1280c64ca 0571/me-of-e-resourcesinkenya.htm(Accessed22.10.2016).
[30] Siddique, M. A. and Ali, A.(2010), Online journals in the Jawaharlal Nehru University (JNU): ausersurvey. Trends in Information Management, 6(1), 41-50.

[31] Babalhavaeji, F. and Anaraki, L. N. (2013), "Investigating the awareness and ability of medical students in using electronic resources of the integrated digital library portal of Iran:Acomparativestudy", Electronic Library, Vol. 31 No: 1, pp. 70-83.

[32] Muneja, P. (2013), A Reflection of Tanzanian Libraries in the Digital Age: Challenges and Prospects. Conference for the Tanzania Library Association (TLA) held in February, 2010: Key Note Address, At Mbeya Tanzania. Available online at https://www.researchgate.net/publication/258831780(Accessed 29.10.2016).

[33] Yi, Z. (2016), Effective techniques for the promotion of library services and resources. Information Research, Vol. 21 No 21 No 1, March 2016.

[34] Kaur, K. (2009), "Marketing the academic library on the web", Library Management, Vol. 30 Issue: 6/7, pp. 454-468, https://doi.org/10.1108/01435120910982140.

[35] Al-Awadhi, S. and Al-Daihani, S. M. (2018), "Marketing Academic Library Information Services Using Social Media", Library Management, https://doi.org/10.1108/LM-12-20170132. (Accessed14.08.2018).

[36] Yi, Z. (2014), Australian academic librarians' perceptions of effective Web 2.0 tools used to market services and resources. The Journal of Academic Librarianship, 40(3/4), 220-227.

[37] Sife, A. S. (2013), Web Search Behaviour of Postgraduate Students at Sokoine University of Agriculture, Tanzania Available Online at http://digitalcommons.unl.edu/ libphilprac/897 (Accessed on 31.05.2017).

[38] Hinchliffe, L. J., \& Leon, R. (2011), Innovation as a framework for adopting Web 2.0 marketing approaches. In D. Gupta \& R. Savard. (Ed), Marketing libraries in a Web 2.0 world (pp.58-65). Berlin: De Gruyter Saur.

[39] Moulaison, H. L., \& Corrado, E. M. (2011), Staying free from 'corporate marketing machines 'library policy for Web2.0 tools. In D. Gupta \& R. Savard. (Eds.), Marketing libraries in a Web2.0 world (pp.43-55). Berlin: De Gruyter Saur.

[40] Fields, E. (2010), Aunique twitter use for reference services. Library HiTech News, 27(6), 14-15.

[41] Rodzvilla, J. (2010), New title tweets. Computers in Libraries, 30(5), 27-30.

[42] Stuart, D. (2010), What are libraries doing on twitter? Online, 34(1), 45-47.

[43] Hendrix, D., Chiarella, D., Hasman, L., Murphy, S. \& Zafron, ML. (2009), "Use of Facebook in Academic Health Sciences Libraries". Journal of the Medical Library Association, 97(1), 44-47.

[44] Milstein, S. (2009), Twitter FOR libraries (and librarians). Computers in Libraries, 29 (5), 17-18.

[45] Wema, E. and Manda, P. (2011), The impact of e-resource usage in academic and research institutions in Tanzania. INASP. Available online at https://www.inasp.info/sites/default/files/2018-04/impact_of _e-resources_in_tanzania.pdf. Accessed 05.01.2019. 
[46] Mathews, B. (2009), Marketing today's academic library: a bold new approach to communicating with students. Chicago, IL: American Library Association.
[47] Nkebukwa, L. L. (2016), Statuson the Usage of ElectronicResources by Studentsat the College of Business Education. Business Education Journal (BEJ), VolumeI, Issue No. 2, Page 1-13. 